\title{
Soursop, a New Host of Rotylenchulus reniformis
}

\author{
Romero M. de Moura ${ }^{1}$, Sandra Roberta V. L. Maranhão \& Lílian M. Paes Guimarães ${ }^{1}$ \\ 1Departamento de Agronomia, Universidade Federal Rural de Pernambuco, Dois Irmãos, Recife, PE, \\ CEP 52171-900, email: romeromoura@yahoo.com.br
}

(Aceito para publicação em 11/02/2005)

Autor para correspondência: Romero Marinho de Moura

\begin{abstract}
RESUMO
Gravioleira, uma nova hospedeira de Rotylenchulus reniformis

Este trabalho reporta o primeiro assinalamento do parasitismo de Rotylenchulus reniformis em gravioleira (Annona muricata) resultando numa condição de doença na hospedeira. A identificação específica do nematóide foi feita por micrometria de fêmeas imaturas, associada à presença de machos, de acordo com Lehman \& Inserra. A síndrome foi considerada severa, afetando o desenvolvimento do hospedeiro.
\end{abstract}

Soursop (Annona muricata L.), a fruit tree, is a highvalue cash crop in northeastern Brazil and the variety Morada is the most often used due to its early production of fruits of excellent size and high brix of the fruit juice (Figure 1A). On the other hand, this genotype is highly susceptible to a severe disease prevalent in the region [Moura et al., Fitopatol. Bras. 23:173-175. 1998] caused by Pratylenchus coffeae (Zimm.) Filip. \& Stekh. which causes sudden death. This paper reports for the first time an observation of the parasite Rotylenchulus reniformis Linford \& Oliveira, on four-month old soursop plants resulting in disease of the host. The syndrome was considered as severely affecting the host development. Only immature vermiform females, males and juveniles of $R$. reniformis were found to be consistently associated with affected plants. Species identification of the pathogen was based on the morphometry of immature females and presence of males, according to Lehman \& Inserra (1990) (Morphometric variation of Rotylenchulus parvus and Rotylenchus reniformis populations in the southern United States. Soil and Crop Sci. Soc. Fla. Proc. 49:220-226. 1990). Specimens used for measurements were extracted from soil rhizosfere and observed under light microscope using routine procedures. The numerical data obtained were considered similar to those presented by the cited authors and showed a very high presence of males. Concerning the disease, reniform nematode parasitism resulted in a very typically high level of isolate necrosis on younger roots and coalescent necrosis along the older roots (Figure 1B). Follow up disease severity revealed the evolution of secondary symptoms basically stunting, yellowing and defoliation. Reniform females without and with egg mass (Figure $1 \mathrm{C}$ and $\mathrm{D}$ ) were observed to protrude from isolated root necrosis. Rotylenchulus reniformis can be hosted by many different cash crop plants (Ayala \& Ramirez J. Agric. Uni. of Porto Rico 48:140-161. 1964) and by weeds (Inserra et al., Weed hosts of Rotylenchulus reniformis in ornamental nurseries of southtern Florida. Fla. Dept. Agric. \& Con. Serv.
Nematology Circular 171. 1989). In northeastern Brazil this pathogen is highly virulent in cilantro (Coriandrum sativum L.) and melon (Cucumis melo L.) and has been reported to be associated with other important crops such as sugarcane (hybrids of Saccharum spp.), yam (Dioscorea cayennensis Lam.), papaya (Carica papaya L.), banana (Musa sp.) and pineapple [Ananas comosus (L.) Merr.] although these associations have not produced damages in these crops (Moura et al. Fitonematóides de interesse agrícola assinalados pelo Laboratório de Fitonematologia da UFRPE em Pernambuco e estados visinhos. Resumos, $37^{\circ}$ Congresso Brasileiro de Fitopatologia, p. 143b. 2004).

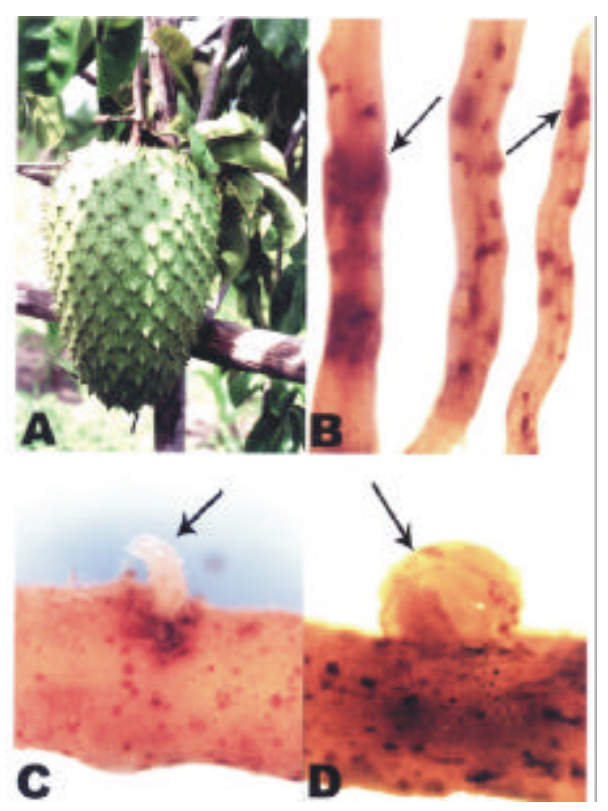

FIG. 1 - A) Mature fruit of soursop (Annona muricata) var. Morada at havesting time ; B) Coalescent necrosis on older roots and isolated on younger ones ; C and D) Mature females protruding from a local lesion without and with egg mass. 